\title{
Pengaruh Pemupukan Nitrogen Terhadap Tinggi dan Percabangan Tanaman Teh (Camelia Sinensis (L.) O. Kuntze) untuk Pembentukan Bidang Petik
}

\author{
The Effect of Nitrogen Fertilization on High and Branching Tea Plant (Camelia sinensis (L.) O. Kuntze) \\ Frame Formation
}

\author{
Miftah Anugrah Pamungkas dan Supijatno* \\ Departemen Agronomi dan Hortikultura, Fakultas Pertanian, Institut Pertanian Bogor \\ Jalan Meranti, Kampus IPB Darmaga, Bogor 16680, Indonesia \\ Telp.\&Faks.62-251-8629353, e-mail: agronipb@indo.net.id \\ *Penulis untuk korespondensi: supijatno@yahoo.com
}

Disetujui 17 Mei 2017/Published online 22 Mei 2017

\begin{abstract}
The objective of this research was to investigate the effect of various dosage of Nitrogen fertilizer on high and branching of tea plant (Camelia sinensis (L.) O. Kuntze). Research was conducted from February until June 2012 at Cikabayan Atas Experimental Station, IPB, Darmaga, Bogor. Experiment consists of one factor, arranged in Randomized Block Design with four replication. The treatments applied were (P0:60 kg

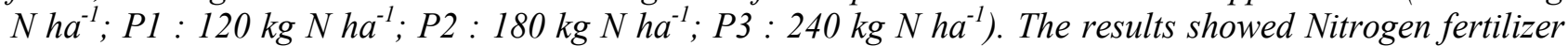
significantly affect plant height in the third week of observation, number of leaves in the ninth until the seventeenth week of observation, the diameter of the stem in the first to the fourth week of observation and sub-branches. P2 treatment (180 $\left.\mathrm{kg} \mathrm{N} \mathrm{ha}^{-1}\right)$ is the best treatment but did not different with P1 treatment. Nitrogen fertilizer did not significantly affect the number of branches, greenness of leaves and a high percentage of plants greater $70 \mathrm{~cm}$.
\end{abstract}

Keywords: (Camelia sinensis), frame formation, nitrogen fertilizer dosage, centering and bending.

\begin{abstract}
ABSTRAK
Penelitian ini bertujuan untuk mengetahui pengaruh berbagai dosis pupuk nitrogen terhadap tinggi dan percabangan tanaman teh (Camelia sinensis (L.) O. Kuntze). Penelitian dilaksanakan pada Februari hingga Juni 2012 di Kebun Percobaan Cikabayan Atas IPB, Darmaga, Bogor. Penelitian ini merupakan percobaan satu faktor dengan menggunakan Rancangan Acak Kelompok (RAK) dengan 4 ulangan. Perlakuan terdiri dari (P0 : $60 \mathrm{~kg} \mathrm{~N} \mathrm{ha-1} ; \mathrm{P1}: 120 \mathrm{~kg} \mathrm{~N} \mathrm{ha}^{-1} ; \mathrm{P2}: 180 \mathrm{~kg} \mathrm{~N} \mathrm{ha}^{-1} ; \mathrm{P3}: 240 \mathrm{~kg} \mathrm{~N} \mathrm{ha}^{-1}$ ). Hasil dari penelitian menunjukkan bahwa pemupukan nitrogen memberikan pengaruh nyata terhadap tinggi tanaman pada minggu kedua pengamatan, jumlah daun pada minggu kedelapan hingga minggu keenam belas pengamatan, diameter batang pada minggu pertama hingga minggu ketiga pengamatan serta pada pengamatan cabang sekunder. Secara keseluruhan perlakuan $180 \mathrm{~kg} \mathrm{~N} \mathrm{ha}^{-1}$ merupakan perlakuan terbaik tetapi tidak berbeda dengan perlakuan $120 \mathrm{~kg} \mathrm{~N} \mathrm{ha}$.- Pemupukan nitrogen tidak berpengaruh nyata terhadap jumlah cabang primer, kehijauan daun serta persentase tinggi tanaman lebih $70 \mathrm{~cm}$.
\end{abstract}

Kata kunci: (Camelia sinensis), dosis pupuk nitrogen, pembentukan bidang petik, centering dan bending 


\section{PENDAHULUAN}

Tanaman teh (Camelia sinensis (L.) O. Kuntze) merupakan tanaman berbentuk pohon yang tingginya dapat mencapai belasan meter. Untuk keperluan perkebunan, tinggi tanaman the dipertahankan sekitar $1.5 \mathrm{~m}$ sehingga bentuknya seperti tanaman perdu. Tanaman ini memiliki nilai ekonomis yang tinggi sehingga banyak dibudidayakan di Indonesia. Produk olahan tanaman teh memiliki peranan besar dalam mencukupi kebutuhan minuman penyegar di Indonesia selain kopi dan cokelat. Teh merupakan sumber antioksidan yang cukup bagi tubuh bila dikonsumsi secara teratur. Wibowo dalam Mangeonsoekarjo (2007) menyatakan bahwa tanaman teh di Indonesia didominasi oleh teh yang jenis assamica (Camilia sinensis var. assamica) lebih banyak memiliki zat antioksidan yang mencapai 12-14 \% seperti polifenol, thianmin, katekin, derivatnya dibandingkan dengan jenis sinensis (Camelia sinensis var. sinensis).

Produksi teh di Indonesia cenderung menurun dari tahun ke tahun. Pada tahun 2007 dengan luas lahan 77,600 hektar mampu memproduksi 116501 ton daun teh kering, angka tersebut lebih tinggi dibandingkan dengan produksi tahun 2008 sebesar 114,689 ton dengan luas perkebunan yaitu 78,900 hektar. Pada tahun 2009 produksi menurun dengan menyempitnya luasan perkebunan menjadi 66,900 hektar dan hanya menghasilkan 107,350 ton daun teh kering. Pada tahun 2010 produksi kembali meningkat menjadi 108,963 ton dengan adanya pertambahan. luas menjadi 67,400 hektar (Badan Pusat Statistik, 2012)

Tingkat produktivitas teh di Indonesia saat ini hanya sebesar $\pm 1,300 \mathrm{~kg} / \mathrm{ha} / \mathrm{th}$, atau $60 \%$ dari produktivitas potensial yang dimiliki kebun yaitu $2000 \mathrm{~kg} / \mathrm{ha} / \mathrm{th}$ (Sultoni, 2010). Rendahnya tingkat produktivitas dan produksi the Indonesia disebabkan karena $44 \%$ merupakan perkebunan rakyat, 31\% PT Perkebunan Nusantara, dan 25\% perkebunan swasta (Rochayati, 2011). Upaya peningkatan produksi perlu dilakukan oleh para peneliti di bidang tanaman teh agar dapat menghasilkan tanaman teh yang memiliki produktivitas tinggi, memiliki kualitas yang baik serta berkelanjutan.

Salah satu cara untuk dapat meningkatkan kualitas tanaman teh adalah dengan pemupukan yang tepat serta pembentukan bidang petik dengan tingkat efisiensi yang tinggi. Menurut Hainsworth dalam Wibowo (2007) menyatakan bahwa rumus pemupukan tanaman the sepanjang tahun pada dasarnya hanya berpegang pada N-P-K dengan perbandingan 6-1-2 untuk Andosol, 5-1-2 untuk Latosol, dan 5-1-1 untuk Podzolik. Tujuan utama dari centering adalah untuk memacu pertumbuhan melebar kemudian dilakukan pemangkasan secara selektif setelah adanya cabang-cabang baru pada tanaman. Bending adalah suatu cara pembentukan bidang petik dengan melengkungkan batang utama dan cabangcabang sekunder tanpa mengurangi bagian-bagian tanaman agar merangsang pertumbuhan tunas pada bagian tersebut. Bending dilakukan pada tanaman yang telah memiliki tinggi lebih dari 70 $\mathrm{cm}$. Tanaman tersebut dilengkungkan hingga ujungnya kemudian diikat atau dipasak menggunakan sebilah bambu. Selanjutnya tanaman tersebut dipetik pucuk peko-nya agar menginisiasi cabang dan daun baru. Penelitian ini bertujuan untuk mempelajari pengaruh penggunaan berbagai dosis pupuk nitrogen terhadap pertumbuhan tinggi dan percabangan tanaman teh (Camelia sinensis (L.) O. Kuntze).

\section{BAHAN DAN METODE}

Penelitian ini dilaksanakan di Kebun Percobaan Cikabayan Atas, Departemen Agronomi dan Hotikultura, Institut Pertanian Bogor mulai bulan Februari hingga Juni 2012. Bahan yang digunakan adalah bibit tanaman teh klon Gambung 7 sebanyak 176 bibit, pupuk Urea, serta pupuk kandang kotoran ayam. Alat yang digunakan berupa alat-alat umum untuk membudidayakan tanaman serta alat tulis, saat pengamatan digunakan jangka sorong dan alat ukur klorofil SPAD-502 Plus.

Penelitian ini dilakukan dengan menggunakan faktor tunggal dengan susunan Rancangan Acak Kelompok (RAK). Perlakuan yang digunakan yaitu dosis pupuk $\mathrm{N}$ yang terdiri atas 4 taraf yaitu $\mathrm{P} 0=60 \mathrm{~kg} \mathrm{~N} \mathrm{ha}^{-1}, \mathrm{P} 1=120 \mathrm{~kg} \mathrm{~N}$ $\mathrm{ha}^{-1}, \mathrm{P} 2=180 \mathrm{~kg} \mathrm{~N}^{-1}{ }^{-1}, \mathrm{P} 3=240 \mathrm{~kg} \mathrm{~N}^{-1}$. Empat perlakuan tersebut diulang sebanyak 4 kali, sehingga terdapat 16 satuan percobaan. Masingmasing satuan percobaan terdiri dari 8 tanaman. Data yang diperoleh akan diuji dengan uji $\mathrm{F}$, bila berbeda nyata maka akan dilakukan uji lanjut DMRT pada taraf $5 \%$.

Penelitian dilaksanakan pada 2 blok lahan, masing-masing blok seluas $20 \mathrm{~m} \times 10 \mathrm{~m}$ yang memiliki perbedaan tinggi sekitar $1 \mathrm{~m}$ antar bloknya. Pengolahan tanah dilakukan pada minggu terakhir bulan Oktober 2011 dengan cara menggemburkan tanah kemudian lubang dibuat lubang tanam dengan jarak $120 \mathrm{~cm} \times 60 \mathrm{~cm}$. setiap lubang tanam diberi pupuk organik kotoran ayam dengan dosis $1 \mathrm{~kg}$ per lubang tanam. Dua minggu kemudian bibit teh ditanam pada lubang tanam tersebut. perlakuan pemupukan dilakukan pada 
minggu terakhir bulan Februari 2012, dengan cara menaburkan pupuk pada alur di sekeliling tanaman. Perlakuan dosis pupuk hanya dilakukan satu kali aplikasi dikarenakan pupuk yang digunakan adalah pupuk slow release yang efeknya dapat mempengaruhi tanaman beberapa waktu kemudian.

Pengamatan pendahuluan dilakukan pada hari yang sama dengan kegiatan aplikasi pupuk yang bertujuan untuk mengetahui kondisi awal tanaman serta nilai peubah-peubah pengamatan. Tanaman yang telah mencapai tinggi lebih dari 70 $\mathrm{cm}$ ataupun cabang primer yang telah memilii panjang lebh dari $70 \mathrm{~cm}$ dilakukan bending pada mingu selanjutnya dan tidak dilakukan pengamatan tinggi tanaman.

Pada pertanaman the dilakukan kegiatan pemeliharaan yang meliputi pengendalian gulma dan hama penyakit tanaman. Pengendalian gulma dilakukan secara manual sesuai dengan perkembangan gulma. Pengendalian organisme pengganggu tanaman dilakukan ketika sudah terdapat gejala serangan pada tanaman dengan membuang bagian tanaman yang terserang ataupun membuang/menjauhkan hama tersebut dari tanaman.

\section{HASIL DAN PEMBAHASAN}

Kondisi iklim selama percobaan berlangsung adalah curah hujan rata-rata $272.8 \mathrm{~mm}$ per bulan dengan jumlah hari hujan rata-rata 21 hari per bulan. suhu maksimum rata-rata per bulan pada lokasi percobaan adalah $27.5^{\circ} \mathrm{C}$ dan suhu minimum rata-rata yaitu $26.1{ }^{\circ} \mathrm{C}(\mathrm{BMKG}, 2012)$.

\section{Tinggi tanaman}

Hasil uji analisis ragam menunjukkan bahwa pemberian pupuk nitrogen berpengaruh nyata pada tinggi tanaman pada minggu kedua pengamatan (Tabel 1). Minggu kedua memperlihatkan bahwa perlakuan $180 \mathrm{~kg} \mathrm{n} \mathrm{ha}^{-1}$ memiliki tinggi tanaman terbaik diantara semua perlakuan.

Tabel 1. Tinggi tanaman the dengan dosis Nitrogen yang berbeda pada pengamatan minggu kedua

\begin{tabular}{ll}
\hline Perlakuan & Tinggi tanaman $(\mathrm{cm})$ \\
\hline P0 & $52.1 \mathrm{~b}$ \\
P1 & $50.4 \mathrm{~b}$ \\
P2 & $58.9 \mathrm{a}$ \\
P3 & $53.2 \mathrm{ab}$ \\
\hline
\end{tabular}

Keterangan: angka pada kolom yang sama diikuti huruf yang sama tidak berbeda nyata menurut uji DMRT 5\%

Gambar 1 menunjukkan presentase tanaman mencapai tinggi lebih dari $70 \mathrm{~cm}$. perlakuan $180 \mathrm{~kg} \mathrm{~N} \mathrm{ha}^{-1}$ mencapai tinggi lebih dari $70 \mathrm{~cm}$ lebih cepat dibandingkan perlakuan lainnya. Minggu keempat presentasenya selalu tinggi hingga akhir pengamatan.

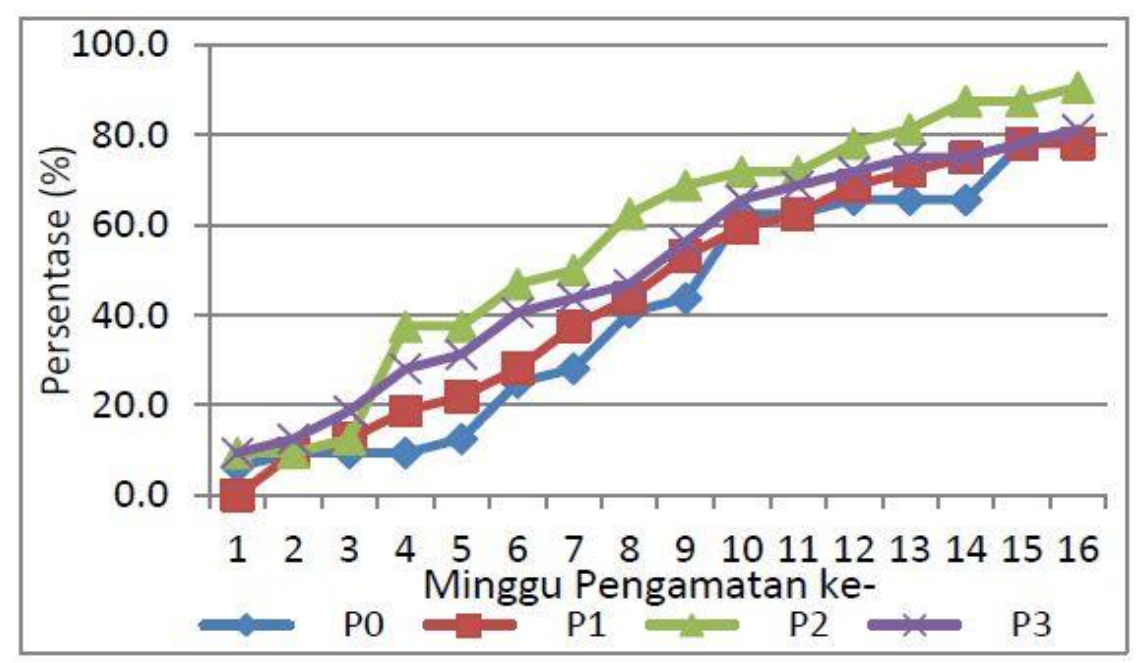

Gambar 1. Persentase tanaman teh yang telah mencapai tinggi $70 \mathrm{~cm}$ pada berbagai dosis pupuk Nitrogen

\section{Jumlah daun}

Hasil uji analisis ragam menunjukkan bahwa pemberian pupuk Nitrogen berpengaruh nyata pada jumlah daun pada minggu kedelapan hingga minggu terakhir pengataman (Tabel 2).
Tabel 2 menunjukkan bahwa perlakuan $180 \mathrm{~kg} \mathrm{~N}$ $\mathrm{ha}^{-1}$ memiliki jumlah daun paling banyak dibandingkan dengan semua perlakuan. 
Tabel 2. Jumlah daun tanaman teh pada minggu kesembilan hingga minggu ketujubelas dengan perbedaan perlakuan dosis pupuk Nitrogen

\begin{tabular}{lllll}
\hline \multirow{2}{*}{ Minggu } & \multicolumn{4}{c}{ Jumlah daun (helai } \\
\cline { 2 - 5 } & P0 & P1 & P2 & P3 \\
\hline Ke-8 & $56.1 \mathrm{~b}$ & $62.4 \mathrm{ab}$ & $69.7 \mathrm{a}$ & $59.0 \mathrm{~b}$ \\
ke-9 & $59.1 \mathrm{~b}$ & $66.3 \mathrm{ab}$ & $75.7 \mathrm{a}$ & $64.2 \mathrm{~b}$ \\
ke-10 & $63.1 \mathrm{~b}$ & $71.5 \mathrm{ab}$ & $82.4 \mathrm{a}$ & $68.3 \mathrm{~b}$ \\
ke-11 & $65.8 \mathrm{~b}$ & $75.9 \mathrm{ab}$ & $86.4 \mathrm{a}$ & $71.8 \mathrm{~b}$ \\
ke-12 & $68.1 \mathrm{~b}$ & $78.5 \mathrm{ab}$ & $89.1 \mathrm{a}$ & $75.1 \mathrm{~b}$ \\
ke-13 & $74.2 \mathrm{~b}$ & $86.6 \mathrm{ab}$ & $95.7 \mathrm{a}$ & $83.7 \mathrm{bc}$ \\
ke-14 & $78.4 \mathrm{~b}$ & $90.5 \mathrm{ab}$ & $98.7 \mathrm{a}$ & $89.5 \mathrm{a}$ \\
ke-15 & $88.1 \mathrm{~b}$ & $100.0 \mathrm{ab}$ & $107.8 \mathrm{a}$ & $97.5 \mathrm{ab}$ \\
ke-16 & $92.0 \mathrm{~b}$ & $104.5 \mathrm{ab}$ & $108.8 \mathrm{a}$ & $100.2 \mathrm{ab}$ \\
\hline
\end{tabular}

Keterangan : angka pada baris yang sama dengan diikuti huruf yang sama tidak berbeda nyata menurut uji DMRT 5\%

Gambar 2. menyajikan perkembangan jumlah daun selama percobaan. Perlakuan $180 \mathrm{~kg} \mathrm{~N}$ $\mathrm{ha}^{-1}$ selalu lebih tinggi daripada perlakuan lainnya. Perbedaan jumlah daun terendah pada minggu ketujuh yaitu $180 \mathrm{~kg} \mathrm{~N} \mathrm{ha}^{-1} 57.1$ helai sedangkan
$120 \mathrm{~kg} \mathrm{~N} \mathrm{ha-1} 55.3$ helai sedangkan perbedaan jumlah daun paling tinggi terdapat pada minggu kesebelas yaitu $180 \mathrm{~kg} \mathrm{~N} \mathrm{ha}^{-1} 82.4$ helai dan $120 \mathrm{~kg}$ $\mathrm{N} \mathrm{a}^{-1} 71.5$ helai.

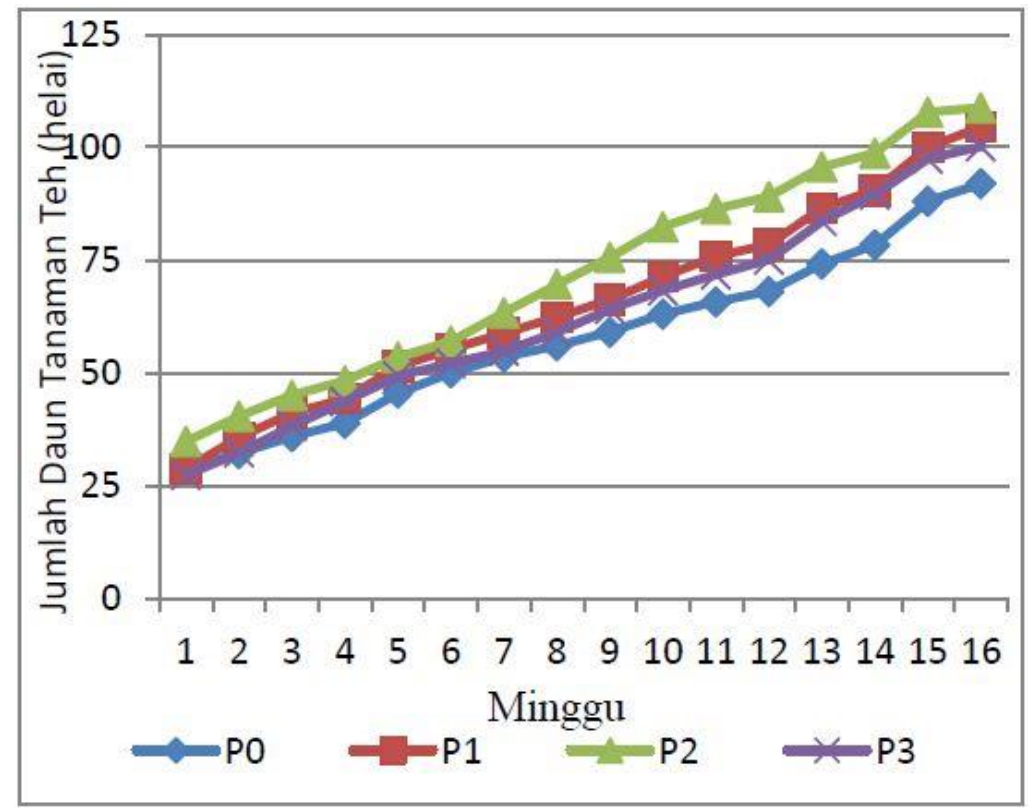

Gambar 2. Jumlah daun tanaman teh pada perlakuan perbedaan dosis pupuk Nitrogen

\section{Diameter batang}

Hasil analisis ragam menunjukkan bahwa pemberian pupuk Nitrogen berpengaruh nyata pada diameter batang pada minggu pertama hingga keempat, terlihat bahwa perlakuan $180 \mathrm{~kg} \mathrm{~N} \mathrm{ha}^{-1}$ memiliki diameter batang terbaik dibandingkan dengan semua perlakuan. Berdasarkan Tabel 3 perlakuan $180 \mathrm{~kg} \mathrm{~N} \mathrm{ha}^{-1}$ berbeda nyata dengan perlakuan $60 \mathrm{~kg} \mathrm{~N}^{-1}$ dan $240 \mathrm{~kg} \mathrm{~N}^{-1}$ tetapi berbeda nyata dengan perlakuan $120 \mathrm{~kg} \mathrm{~N} \mathrm{ha}^{-1}$.
Tabel 3. Diameter batang dengan perbedaan perlakuan dosis pupuk Nitrogen pada minggu pertama hingga minggu ketiga pengamatan.

\begin{tabular}{lllll}
\hline \multirow{2}{*}{ Minggu } & \multicolumn{4}{c}{ Diameter batang $(\mathrm{cm})$} \\
\cline { 2 - 5 } & P0 & P1 & P2 & P3 \\
\hline ke-1 & $0.40 \mathrm{~b}$ & $0.42 \mathrm{~b}$ & $0.44 \mathrm{a}$ & $0.40 \mathrm{~b}$ \\
ke-2 & $0.43 \mathrm{~b}$ & $0.45 \mathrm{~b}$ & $0.49 \mathrm{a}$ & $0.46 \mathrm{~b}$ \\
ke-3 & $0.44 \mathrm{~b}$ & $0.46 \mathrm{ab}$ & $0.49 \mathrm{a}$ & $0.45 \mathrm{~b}$ \\
ke-4 & $0.45 \mathrm{~b}$ & $0.45 \mathrm{~b}$ & $0.49 \mathrm{a}$ & $0.44 \mathrm{~b}$ \\
\hline
\end{tabular}

Keterangan: angka pada baris yang sama dengan diikuti huruf yang sama tidak berbeda nyata menurut uji DMRT 5\%

Gambar 3 menunjukkan diameter batang 
selama pengamatan. Perlakuan $180 \mathrm{~kg} \mathrm{~N}$ ha $^{-1}$ selalu lebih tinggi daripada perlakuan lain, padahal pada minggu keempat nilainya hampir sama dengan perlakuan $120 \mathrm{~kg} \mathrm{~N} \mathrm{ha}$. Pengamatan terakhir diameter batang perlakuan $180 \mathrm{~kg} \mathrm{~N}^{-1}$ memiliki hasil yang paling baik dengan diameter rata-rata $0.88 \mathrm{~cm}$.

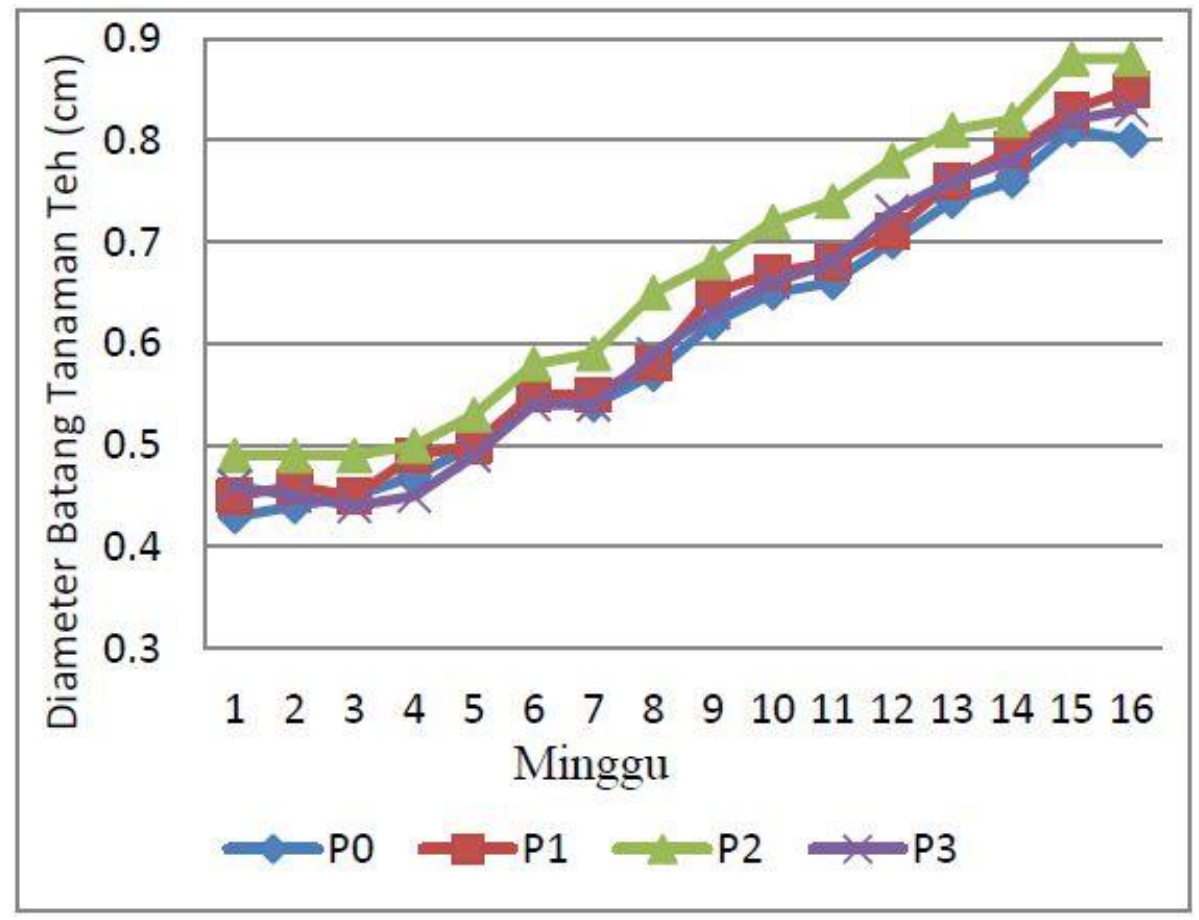

Gambar 3. Diameter batang tanaman teh

Jumlah Cabang Primer dan Jumlah Cabang Sekunder

Hasil uji analisis ragam menunjukkan bahwa pemberian pupuk nitrogen berpengaruh nyata pada jumlah cabang sekunder sedangkan pada jumlah cabang primer tidak berpengaruh nyata (Tabel 4). Tabel 4 menunjukkan bahwa jumlah cabang primer dan cabang sekunder terbanyak pada perlakuan $180 \mathrm{~kg} \mathrm{~N}^{-1}$. Jumlah cabang sekunder pada perlakuan $180 \mathrm{~kg} \mathrm{~N}^{-1}$ berbeda nyata dengan perlakuan $60 \mathrm{~kg} \mathrm{~N} \mathrm{ha}^{-1}$ tetapi tidak berbeda nyata dengan perlakuan $120 \mathrm{~kg} \mathrm{~N}^{-1}$ dan $240 \mathrm{~kg} \mathrm{~N} \mathrm{ha}^{-1}$. Jumlah cabang sekunder terbaik terdapat pada perlakuan $180 \mathrm{~kg} \mathrm{~N}^{-1}$ yaitu 3.25 sedangkan yang terendah terdapat pada perlakuan $60 \mathrm{~kg} \mathrm{~N} \mathrm{ha}^{-1}$ sebesar 1.42 .

Tabel 4. Jumlah cabang primer dan cabang sekunder tanaman teh dengan perlakuan perbedaan dosis pupuk Nitrogen

\begin{tabular}{lll}
\hline \multirow{2}{*}{ Perlakuan } & \multicolumn{2}{c}{ Jumlah cabang } \\
\cline { 2 - 3 } & Primer & \multicolumn{2}{c}{ Sekunder } \\
\hline P0 & 6.23 & $1.42 \mathrm{~b}$ \\
P1 & 6.48 & $2.42 \mathrm{ab}$ \\
P2 & 7.14 & $3.25 \mathrm{a}$ \\
P3 & 6.66 & $1.97 \mathrm{ab}$ \\
\hline
\end{tabular}

Keterangan: angka pada kolom yang sama diikuti huruf yang sama tidak berbeda nyata menurut uji DMRT 5\%
Waktu yang dibutuhkan tanaman teh untuk mencapai tinggi $70 \mathrm{~cm}$

Hasil uji analisis ragam menunjukkan bahwa pemberian pupuk nitrogen tidak berpengaruh nyata pada lama waktu tanaman mencapai tinggi 70 $\mathrm{cm}$. Waktu yang dibutuhkan tanaman untuk mencapai tinggi $70 \mathrm{~cm}$ tidak berbeda antar perlakuan. Tabel 5 mmenunjukkan tanaman yang diberi perlakuan $180 \mathrm{~kg} \mathrm{~N} \mathrm{ha}^{-1}$ dengan waktu sekitar 8 minggu, selanjutnya perlakuan $240 \mathrm{~kg} \mathrm{~N}$ ha $^{-1}$ dengan waktu 9 minggu sedangkan $60 \mathrm{~kg} \mathrm{~N}$ ha ${ }^{1}$ dan $120 \mathrm{~kg} \mathrm{~N}^{-1}$ mencapai tinggi $70 \mathrm{~cm}$ dalam waktu 10 minggu. Hal ini disebabkan pada awal pengukuran tanaman pada perlakuan $180 \mathrm{~kg} \mathrm{~N}$ ha ${ }^{1}$ telah memiliki tinggi yang lebih baik dari perlakuan lainnya.

\section{Tingkat Kehijauan daun}

Hasil uji F menunjukkan bahwa perbedaan dosis pupuk yang diberikan tidak berpengaruh nyata pada tingkat kehijauan daun. Tingkat nilai kehijauan daun antar dosis tidak berbeda (Tabel 5). Perlakuan pupuk $180 \mathrm{~kg} \mathrm{~N} \mathrm{ha}^{-1}$ memiliki nilai ratarata tertinggi yaitu sebesar 38.0 satuan unit sedangkan untuk perlakuan $240 \mathrm{~kg} \mathrm{~N} \mathrm{ha}^{-1}, 120 \mathrm{~kg} \mathrm{~N}$ 
$\mathrm{ha}^{-1}$ dan $60 \mathrm{~kg} \mathrm{~N} \mathrm{ha}^{-1}$ secara berturut-turut yaitu 35.8 , 34.7 dan 33.7 satuan unit.

Tabel 5. Rataan tingkat kehijauan daun serta waktu yang dibutuhkan untuk mencapai tinggi 70 $\mathrm{cm}$ pada tanaman teh dengan pemberian dosis pupuk yang berbeda

\begin{tabular}{llr}
\hline Perlakuan & $\begin{array}{l}\text { Tingkat } \\
\text { kehijauan } \\
\text { daun }\end{array}$ & $\begin{array}{l}\text { Lama waktu tanaman } \\
\text { mencapai tinggi } 70 \mathrm{~cm} \\
\text { (minggu) }\end{array}$ \\
\hline P0 & 33.7 & 10.3 \\
P1 & 34.7 & 10.2 \\
P2 & 38 & 8.4 \\
P3 & 35.8 & 9.4 \\
\hline
\end{tabular}

Keterangan : angka pada kolom yang sama diikuti huruf yang sama tidak berbeda nyata menurut uji DMRT 5\%

Dalimonthe dan Johan (2008) menyatakan bahwa pemilihan cara pembentukan bidang petik dapat mempercepat penutupan perdu sehingga masa tanaman belum menghasilkan (TBM) dapat dipersingkat pembentukan bidang perik dilakukan pada masa tanaman belum menghasilkan (TBM) yang didominasi pertumbuha vegetatifnya sehingga kecukupan Nitrogen dalam tanah perlu diperhatikan. Rachmiati (1988) menyebutkan bahwa nitrogen merupakan hara utama untuk pertumbuhan dan produksi tanaman teh, karena bagian yang dipanen adalah pucuk (tunas muda) yang merupakan bagian vegetatif tanaman. Syarief dalam Rachmiati et al. (2004) menambahkan bahwa pupuk nitrogen diperlukan tanaman untuk pembentukan atau pertumbuhan bagian-bagian vegetatif tanaman seperti daun, batang dan akar.

Perlakuan pemberian pupuk nitrogen berpengaruh nyata terhadap tinggi tanaman pada minggu kedua pengamatan. Hal ini diduga tanaman memiliki kemampuan memanfaatkan nitrogen dalam tanah pada minggu-minggu awal pengamatan sehingga hasil tinggi pada tanaman berbeda dengan perlakuan lainnya. Ketersediaan nitrogen dalam tanah dipengaruhi antara lain oleh bahan organik tanah, kadar air tanah, suhu serta fiksasi nitrogen oleh baktreri tanah. Hasil percobaan menunjukkan bahwa perlakuan $180 \mathrm{~kg} \mathrm{~N} \mathrm{ha}{ }^{-1}$ menghasilkan pertumbuhan yang lebih baik serta memiliki kemampuan untuk mencapai tinggi lebih dari $70 \mathrm{~cm}$ lebih cepat dibandingkan perlakuan lainnya. Pada perlakuan $180 \mathrm{~kg} \mathrm{~N} / \mathrm{ha}$, tanaman telah dapat dilakukan bending dalam waktu 8 minggu setelah perlakuan, sedangkan perlakuan lainnya baru dapat dilakukan bending pada 10 minggu setelah perlakuan.

Pertambahan tinggi tanaman tersebut sangat dipengaruhi oleh ketersedian nitrogen dalam tanah (Rusmana dan Salim, 2003), yang menyatakan bahwa peranan unsur nitrogen bagi tanaman adalah untuk merangsang pertumbuhan tanaman secara keseluruhan, khususnya batang, cabang dan daun. Ketersediaan nitrogen pada penelitian ini terdapat pada kategori sedang walaupun penambahan dosisnya berbeda tiap perlakuan sehingga pertumbuhannya berbeda pada minggu kedua pengamatan. Jumlah daun pada suatu tanaman sangat berperan penting bagi perkembangan tanaman karena daun sebagai media terjadinya proses fotosintesis yang menghasilkan energi bagi tanaman untuk tumbuh. Pemberian pupuk nitrogen berpengaruh nyata pada jumlah daun pada minggu kedelapan hingga minggu keenam belas. Hasil menunjukkan bahwa jumlah daun pada perlakuan $180 \mathrm{~kg} \mathrm{~N} \mathrm{Na}^{-1}$ memiliki jumlah daun paling banyak dibandingkan dengan perlakuan lain, tetapi perlakuan $120 \quad \mathrm{~kg} \quad \mathrm{~N}^{-1}$ memiliki pertambahan jumlah daun yang lebih baik. Hal tersebut dapat menunjukkan bahwa perlakuan $120 \mathrm{~kg} \mathrm{~N} \mathrm{ha}^{-1}$ lebih efektif untuk pertambahan jumlah daun tanaman teh. Menurut Hanafiah (2005) penggunaan pupuk nitrogen berperan menonjol terhadap bagian vegetatif tanaman (dedaunan dan pucuk). Penggunaan dosis yang tepat akan lebih mengoptimalkan hasil pucuk dari tanaman teh.

Pada dua bulan terakhir pengamatan curah hujan sangat rendah sehingga kadar air tanah berkurang (Hall, 2007), menyatakan bahwa tanaman membutuhkan dosis pupuk nitrogen yang tepat bagi kecepatan tanaman untuk tumbuh, khususnya pada saat cuaca panas atau ketika tanah menunjukkan kekeringan. Hal tersebut menunjukkan bahwa tanaman membutuhkan nitrogen pada saat tanah kekurangan air, walaupun ketersediaan nitrogen dalam tanah tinggi tetapi tanaman belum membutuhkan maka tidak akan mempengaruhi pertumbuhan tanaman.

Pemberian pupuk nitrogen yang berbeda memberikan pengaruh yang nyata pada diameter batang tanaman teh pada pengamatan minggu pertama hingga minggu ketiga. Diameter batang pada perlakuan $180 \mathrm{~kg}$ N/ha telah memiliki nilai yang lebih tinggi pada awal pengamatan tetapi setelah dilakukan uji lanjut DMRT, pada minggu tersebut perlakuan $180 \mathrm{~kg}$ N/ha memang lebih baik bila dibandingkan dengan perlakuan lainnya. Diameter batang pada perlakuan $180 \mathrm{~kg} \quad \mathrm{~N} / \mathrm{ha}$ meningkat lebih cepat tiap minggunya sedangkan perlakuan lain peningkatannya stagnan. Hal tersebut didukung dengan ketersediaan air pada bulan pertama pengamatan dengan curah hujan yang cukup tinggi. Menurut Hanafiah (2005) air yang diserap tanaman selain sebagai komponen sel-selnya, 
juga berfungsi sebagai media reaksi pada hampir seluruh proses metabolismenya. Metabolisme nitrogen dalam tanaman merupakan faktor utama untuk pertumbuhan vegetatif, batang, dan daun tanaman sehingga terdapat pengaruhnya pada pertambahan diameter batang tanaman teh tersebut.

Pada penghitungan jumlah cabang primer dan sekunder, dosis pupuk nitrogen berpengaruh nyata pada jumlah cabang sekunder sedangkan pada jumlah cabang primer tidak berpengaruh nyata. Hasil yang berbeda antara jumlah cabang primer dan cabang sekunder ini sangat berkaitan dengan genetik dari tanaman tersebut. Klon tanaman teh yang berbeda memungkinkan dapat mempengaruhi perbedaan antara jumlah cabang primer dan sekunder sehingga berbeda nyata hanya pada cabang sekunder. Lina et al. (2009) menemukan bahwa pemupukan nitrogen memberikan pengaruh yang nyata terhadap jumlah anak daun sedangkan tidak berpengaruh nyata pada jumlah daun. Tiap tanaman memiliki genetik yang berbeda untuk pertambahan jumlah cabang primer dan cabang sekunder, sehingga masih sangat sulit untuk mengetahuinya.

Menurut Barchia (2009) dalam suatu tanaman, nitrogen berfungsi sebagai penyusun penting dari klorofil, protoplasma, protein, peningkat pertumbuhan dan perkembangan semua jaringan. Kandungan klorofil pada daun dapat diketahui dengan mengukur tingkat kehijauan daun pada suatu tanaman. Hasil pengukuran kehijauan daun didapatkan bahwa antar perlakuan tidak berbeda nyata. Hal tersebut menunjukkan bahwa pengaruh nitrogen sangat kecil terhadap tingkat kehijauan daun walaupun terdapat daun dengan tingkat kehijauan yang tinggi. Tingkat kehijauan daun menunjukkan bahwa tanaman memiliki kadar nitrogen yang cukup serta menunjukkan kondisi pertanaman yang sehat. Pengukuran tingkan kehijauan ini dilakukan untuk meningkatkan efisiensi penggunaan pupuk nitrogen. Pengelolaan unsur hara serta aplikasi pupuk adalah faktor yang sangat menentukan pencapaian serapan hara yang optimal bagi produksi tanaman yang tinggi.

Penelitian ini menunjukkan bahwa penambahan pupuk nitrogen dengan dosis $180 \mathrm{~kg} / \mathrm{ha}$ dapat menghasilkan pertumbuhan tanaman yang lebih baik dibandingkan dengan perlakuan dosis pupuk yang lainnya, tetapi semakin tinggi dosis yang diberikan tidak berkorelasi positif terhadap tanaman teh. Hal tersebut mungkin terjadi akibat pencucian nitrogen dalam tanah sehingga pengaruh penambahan pupuk nitrogen tidak berpengaruh pada tanaman teh. Jika terdapat kelebihan jumlah nitrogen maka bergantung pada kapasitas tanaman menyerap nitrogen untuk digunakan sebagai pertumbuhan vegetatif tanaman teh.

\section{KESIMPULAN}

Dari hasil penelitian ini menunjukkan bahwa pemberian pupuk nitrogen berpengaruh nyata terhadap pertumbuhan tinggi dan percabangan tanaman teh. Perlakuan pupuk 180 $\mathrm{kg} \mathrm{N}$ ha ${ }^{-1}$ menghasilkan pertumbuhan tanaman yang lebih baik pada peubah tinggi tanaman, jumlah cabang primer dan cabang sekunder, serta diameter batang. Jumlah daun pada perlakuan 180 $\mathrm{kg} \mathrm{N} \mathrm{ha}^{-1}$ dan $120 \mathrm{~kg} \mathrm{~N} \mathrm{ha}^{-1}$ tidak berbeda nyata, tetapi pertambahan jumlah daun perlakuan $120 \mathrm{~kg}$ N/ha lebih besar dibandingkan perlakuan $180 \mathrm{~kg} \mathrm{~N} \mathrm{ha}{ }^{-1}$. Perlakuan pupuk $180 \mathrm{~kg} \mathrm{~N} / \mathrm{ha}$ menghasilkan tinggi tanaman lebih cepat untuk mencapai $70 \mathrm{~cm}$ hanya dengan waktu 8 minggu serta jumlah cabang rata-rata 7.14 dan jumlah anak cabang rata-ratanya 3.25 lebih banyak daripada perlakuan lainnya. Kondisi ini lebih memudahkan untuk pembentukan bidang petik.

\section{DAFTAR PUSTAKA}

Badan Pusat Statistik. 2012. Luas Tanaman Perkebunan dan Produksi Teh 20072010.http://www.bps.go.id/tab_sub/view.p hp?kat=3\&tabel=1\&daftar=1\&id_subyek= $54 \&$ not $\mathrm{ab}=1$ [2 Oktober 2012]

Hall, R. E. 2007. Soil Essential.Managing Your Farms Primary Asset. Collingwood (AU): Landlinks Press.

Hanafiah, K.A. 2005. Dasar-Dasar Ilmu Tanah. Jakarta (ID) : Raja Grafindo Persada.

Lina, S.B, M. Okazaki, D. S. Kimura, Y. Yano, K. Yonebayashi, M. Igura, M. A. Quevedo and A. B. Loreto. 2009. Nitrogen uptake by sago palm (Metroxylon sagu Rottb.) in the early growth stages. Soil Science and Plant Nutrition. 55: 123-144.

Rachmiati, Y. 1998. Pokok-pokok Pemupukan pada Tanaman Teh. Kursus Mandor Tanaman Teh. Lembaga Pendidikan Perkebunan Kampus Yogyakarta. Yogyakarta. 8 hal. Dalam Wachjar, A., Supijatno dan D. Rubiana. 2006. Pengaruh Beberapa Jenis Pupuk Hayati tehadap Pertumbuhan Dua Klon Tanaman The (Camelia sinensis 
(L) O. Kuntze) Belum Menghasilkan. Buletin Agronomi (34) :(3) 160-164.

Rochyati. 2011. Lahan berkurang, produksi teh terancam. [Internet] [diunduh 2012 Okt 12] tersedia pada http://www.bisnis.com/articles/lahanberkurang-produksi-teh-terancam.

Sultoni. 2010. Butuh Rp.1,5 triliun untuk dongkrak produksi the nasional. [Internet] [diunduh 2011 Nov 28] tersedia pada http://bisnisjabar.com/index.php/2011/11b utuh-rp15-triliun-untuk-dongkrakproduksiteh-nasional/

Wibowo, Z.R. 2007. Manajemen tanah dan pemupukan perkebunan teh, p. 293-340. In S. Mangoensoekarjo (Ed). Manajemen Tanah dan Pemupukan Budidaya Perkebunan. Yogyakarta (ID): Gajah Mada University Press.
Barchia, M.F. 2009. Agroekosistem Tanah Mineral Asam. Gajah Mada University Press. Yogyakarta

Syarief, S. 1993. Ilmu Tanah Pertanian. Bandung. Pustaka Buana. Dalam Racmiati, Y., A.A. Salim dan S. Wibowo 2004. Pengaruh berbagai takaran pupuk majemuk NPK dan kompos limbah kulit kina terhadap $\mathrm{pH}$, KTK, C-Organik, dan pertumbuhan tanaman kina muda di inceptisol. Jurnal Penelitian Teh dan Kina. Bandung. 9 (1-2):21-27

Rusmana, N. dan A.A. Salim. 2003. Pengaruh kombinasi pupuk daun puder dan takaran pupuk N, P, K yang berbeda terhadap hasil pucuk tanaman teh (Camelia sinensis (L) O. Kuntze) seedling, TRI 2025 dan GMB 4. Jurnal Penelitian Teh dan Kina. Bandung. 9 (1-2): 28-39. 